\title{
The impact of inclusion on the Spanish education system.
}

\author{
El impacto de la inclusión en el sistema educativo español.
}

\author{
Cristina Pinto Díaz \\ Universidad de Jaén (España) \\ cristipinto96@gmail.com \\ Lucía Melero García \\ Universidad de Jaén (España) \\ luciamelerogarcia92@gmail.com \\ Ana Isabel Chica Díaz \\ Universidad de Jaén (España) \\ anaisabel-chica@hotmail.com
}

Fecha recepción: 29/10/2019

Páginas 109-117

Fecha aceptación: 25/12/2019

\begin{abstract}
.
This project aims to show a broader vision of educational inclusion nowadays. Through different authors and perspectives, the historic evolution of inclusive education is known, from integration to inclusion. In addition, a bibliographic review has been carried out to publicize the different inclusion strategies that can be implemented in the educational field, by the educational community of schools. These strategies can be of different types: strategies of organization and effective management of the classroom (reduction of the ratio, promotion of positive personal relationship, establishment of routines, etc.), teaching strategies and learning assessment (formative os continuous evaluation, motivational strategies, etc.), grouing strategies (according to different sises and criterions) and adaptation of activities and materials' strategies (adaptation of materials, analysis and breakdown of tasks in simpler sequences, etc.).
\end{abstract}

Keywords: inclusion; integration; educational needs; therapeutic pedagogy; inclusion strategies

\section{Resumen.}

Este trabajo pretende mostrar una visión más amplia de la inclusión educativa en la actualidad. A través de diferentes autores y perspectivas se da a conocer la evolución histórica de la educación inclusiva, desde la integración hasta la inclusión. Además, se ha llevado a cabo una revisión bibliográfica para dar a conocer las diferentes estrategias de inclusión que se pueden poner en práctica en el ámbito educativo, por parte de la comunidad educativa de los centros de enseñanza. Estas pueden ser de diferentes tipos: de organización y manejo efectivo del aula (reducción de la ratio, fomento de las relaciones personales positivas, establecimiento de rutinas, etc.), de enseñanza y evaluación de los aprendizajes (evaluación formativa o continua, 
estratégias de motivación, etc.), de agrupamento (atendiendo a diferentes tamaños y critérios) y de adaptación de las atividades y de los materiales (análisis y descomposición de tareas en secuencias más simples, adaptación de materiales, etc.).

Palabras clave: inclusion; integración; necesidades educativas; pedagogía terapéutica; estrategias de inclusión

\section{1.-Introduction.}

Nowadays, attention to diversity should be considered as a fact that goes further than integration, that is to say, it should be contemplated from inclusion, so that promote the presence, involvement and progress of all student body in the education field (Ainscow, Booth \& Kingston, 2006).

Recently, Inclusion have had relevance specially, if it is related with student body that introduce special educational needs special and specific education need.

In order to carry out inclusion, some conditions are necessary. First of all, the raising awareness of the entire educational community is required, because it is something that benefits all of us. Moreover, it is essential that some policies, culture and inclusive practices turn on, because by this way all the society will turn into an inclusive society. (Grande \& González, 2015).

In Spain, a slight historical route about the changes that are produced in diversity; but, currently, there are a lot to research. Some of the most important changes have benefited people who have some type of disability, since it has done all to make possible the fact that nowadays they can be assisted to cover its necessity and trying that people could have less difficult fewer and fewer. (Pérez, 2016).

At the end of XVIII century, the concept of especial education didn't exist. This concept was term of rejection, ignorance and abandonment to disability people. (Pérez, 2016) A huge change was produced in XIX century, so these people began to be assisted. This fact was the reason why the concept of Especial Education was born. Although, they were just helped in assistance ways, never in educational conditions because people were separated of ordinary school ambient. (Pérez, 2016).

Warnock report (1978) helped to the appearance of the concept of Special Educational Needs (NEE) and the society started to focus on the specific support that a person needed in function of his/her different necessities, which can be permanent or transitory.

In the XX century, the legal integration was produced. A fact that demonstrated its evidence was the creation of centers of Especial Education, to people who had a higher rank of disability, and people who had a lower level were assisted in special classes into the ordinary centers.

This especial classes were approved with General Education law (LGE) in 1970, but the integration of these students in the school appeared due to the fact of endorsement of Spanish Constitution in 1978. From this moment, students with necessities were assisted in ordinary centes, and specific centers were used for people who need special education, which could not be treated in the ordinary centers (Gobierno de España, 1970; Gobierno de España, 1978). 
In 1990, thanks to the aprovement of the Organic Law of the General Order of the Educational System (LOGSE), the concept of Special Educational Needs started to gain a real sense and importance and a change in the system towards the diversity began to start up. (Gobierno de España,1990).

In the title II of article of law 2/2006 of 3 of May of Education (LOE) explain that at the end of the education is to get an equity of education center and specific. On the one hand, "Student body that present special educational needs are understood as student body, who needs support or attention educational specific in some moment since that these are is in the school. It is consequence of disability or behaviour grave disorders" (art 73). On the other hand," student body with NEAE is understood as student body, who has necessity special educational, due to the fact different rank and types of personal ability, as physical, psychic, cognitive or sensorial, high ability, late incorporation of education system and student body of compensatory" (art 44.1) (Gobierno de España, 2006).

Some authors establish that should follow one cooperative methodology and collaborative in the classroom, just like, the integration and inclusion to conclude diversity of student body all the time. Although the concept of diversity attention in the school is very bound a NEAE (Hernández \& De Barros, 2016).

Furthermore, other authors defend that all students have educational typical individual necessity and specific. They can accede to learning experience necessary and they can socialise and establish in the school curriculum (Ruíz, 2010).

Therefore, educational context offer for student body some academic contain adapt them, according to their necessity and diverse collaborative interaction between members; with the purpose of stimulate, foment, increase opportunities of learning and eradicate barrier for carry out inclusion in the educational center (Jiménez, Lalueza \& Fardella, 2017).

For working a true inclusion is necessary distinguish the integration concept: it is explicated next:

On one hand, in the first moment, the integration definition was appeared, as a process, which consist in answer to diversity of necessity of all student body and satisfy by means of bigger participation in the learning, cultures and communities. Moreover, the integration, which is to reduce the exclusion in the educational range. (Booth,1996)

On the other hand, years later, the UNESCO (2008) defines of inclusion term, as a process of approach and answer of diversity of necessity of all student body through of increasing participation of learning, cultures and communities and reduction of exclusion in and since education. According to the same Conference International of Education of 2008, the inclusion term has increased, so that all children and young should have equality conditions and opportunities of learning in different types of school, independently of them previous social and cultures of difference abilities and capacities.

Thus, the inclusion education is considered one process of change. This process allows to tackle the necessity of students, who present some diversity, in this way is formed the capacity that should have of inclusive school of accept of all student body, who wants to participate in the school. In this way, the exclusion of student body is reduced (Contreras \& Salazar, 2018). 
Although, the definition of inclusive education or inclusive school does not share totally between the professionals of education of inclusion, it is understood as the acceptance of all student body. In order to, they can participate in the school. Always, the participation have to be accord with capacities of each one. One inclusive school provides to help to student body and opportunities, which are necessary for them academic and personal progress.

Some authors, tag that people are different and have various capacity of think and learning. These authors, carry that there is not one intelligence method. If not one variety, which open minds for each someone. With this makes evidence of diversity and necessity of increasing of necessity of every student (Gardner, 2006).

In conclusion, inclusive education remodellings suppose inspect the agreement and integrating previous reforms and process of form one scale, which does not answer "especial" necessity, just. Unless, the school answers to diversity of necessity of all student body (Lipsky \& Gartner,1996).

The main agent promoting positive and healthy inclusion in the classroom is the teacher. "The teacher is supposed to leave aside his role as a technological representative, who only deals with objectives, purposes and curriculum designed by Government. Instead, he must become a critical person determined to defend their rights as professionals and their students' as well. Given that situation, schools and classrooms will be suitable place for everyone, independently of each student's intelectual ability" (Molina 1996, p. 18).

As explain some authors, the training of teachers in order to education inclusion is important subject in informs and political debates in the latter year. In order to be possible education inclusion of student body is necessary to focus in education and show that can not progress in this plane, without improve (Vaillant, 2009).

In order to one teacher performs her/his work in the inclusive school is necessary that the teacher shows one positive attitude for dfference, teaching, work and problems resolution of cooperative form, these are crucial factors in the process (Blanco, 1999; Damm, 2008).

Some investigations show result about attitude and incoming of teachers for inclusion student body with special educational needs. Some results show that teachers should assign other news education strategies because before they did not use used strategies and strategies used to be poor (Chiner, 2011).

In the inclusion, classroom the teacher appears as a key factor in the generation of climes, which allows good development of abilities emotional social, promotes space of communication and exchange between students (Torres et al., 2013).

On the other hand, an essential factor in the creation of positives climes in the classroom, that have relation with involve factors (teachers, students body, executive, fathers and etcetera). When there is a positive clime is created of inclusion in the classroom. Therefore, teachers work the curriculum and they make inclusive education. Moreover, some authors explain that attitude of teacher is fundamental to social inclusion (Hargreaves, 1994; Hodkinson \& Devarakonda,2009; Granada, Pomés \& Sanhueza, 2013).

So, there are various success indication of inclusive practice in the escolar context, which are: (Prepared from, 2006): 
- Various types of disability of student body, who participate in special education.

- The number time that student body of special education was in ordinary classroom.

- $\quad$ The personal number of support available and as they are used.

- The number and diversion type to make special evaluation.

- The perception of members of education community about of their own skills to generate change in their pedagogical practice and curricularmodification, moreover in their abilities for affirm of discipline of students and use in classroom.

- The perception of members of education community about of impact of inclusive practice in other students.

Therefore, the inclusion in education field should be worked by all teachers of staff meeting. Nowadays, in order to children are included in the classroom and education center, the pedagogy therapeutics teacher is in the ordinary classroom of student with necessity. Instead of working with the student of necessity outside of ordinary classroom. In this way, the inclusion process is really implement to students, who have necessity (NEAE).

Therefore, the education have as aim make know the faculty of different strategies of inclusion that exist, today. In order to get one real inclusion and full of all student in the education canters.

\section{2.-Method.}

A compilation and selection of documents has been carried out which have been read, discussed and criticized in order to extract important information and to be able to build an informed discourse, true and consistent with the topic to be discussed in this research.

\section{1.-Design.}

The design of this research has been a bibliographic review of scientific documents and articles related to inclusion strategies carried out by PT teachers with NEAE students in the classroom.

\subsection{1.-Search Strategies.}

The search strategies that have been followed have been, first, a search in the ERIC (Education Resources Information Center) database, and a search has been carried out on Proquest's Psychology Database and on EBSCOhost. When in these databases it was not possible to access the full text there was a link that redirected us to SAGE Journals where there was access to the full text.

The search has been carried out in English, in all databases, with the following search equations: inclusion OR integration AND specific needs for educational support OR special educational needs AND strategies OR resources AND teachers OR therapeutic pedagogy teachers OR special education teachers. 


\subsection{2.-Inclusion and exclusion criteria.}

The inclusion criteria followed were that the studies should be based on the PRACTICE of the PT for inclusion and inclusive strategies for NEAE students.

On the contrary, those articles that showed nothing concerning inclusion have been excluded, NEAE students and the inclusion strategies of NEAE students.

\subsection{3.-Data extraction.}

For data extraction, a search was performed on ERIC, Proquest Psychology Databases and EBSCOhost. Five articles containing information relevant to this review have been selected from the total results of these databases.

\subsection{4.-Data analysis.}

The analysis of these articles has made it possible to detect the different inclusion strategies that can be carried out with students with NEAE by PT teachers. Different classroom structures, groupings, methodologies, materials, resources and areas of development have been taken into account.

\section{3.-Results.}

The inclusive strategies, or inclusive practices, in education are a combination of structures, activities or tasks that afford good opportunities so that all the students learn (Chines, 2011).

Nevertheless, it must have special care with the idea of equity because it does not admit the conception of equality among everybody. The idea of equity suggests strategies to achieve the equality through observation of the personal differences: an essential aspect that should be consider in the education system (Calvo, Camargo \& Gutiérrez, 2006).

In the educational and pedagogical fields, exist the possibility of carry out didactics' strategies. However, these didactics' strategies cannot forget that everybody belong to a group, dubbed community, and, furthermore, they belong to her different economic, political, cultural and social institutions too (Mondaca, Muñoz, Gajardo \& Gairín, 2018). To offer real opportunities to all students equally in the group, singular, social and intellectual fields it is necessary that flexibility be present all the time in the carry out of educational and inclusive strategies and practices. It is essential that teachers, in conjunction with others social actors, focus on the social and educational aspects, since the uniqueness of students must be taken into account and all the valuable that the group approach can contribute to inclusion (Folco, 2013).

At present there are many strategies that attend to the individual characteristics of students and achieve their inclusion in the education system, among them we find didactic, organizational, students grouping and adaptation strategies for the activities that are worked on; strategies that can be used in the classrooms by the teachers (Cardona, Reig \& Ribera, 2000; Chiner, 2011; Vicuña, 2013). 
Chiner (2011) establishes the different strategies that pursue the inclusion of students in this way:

- $\quad$ Strategies for organization and effective classroom management: these are the acts carried out by the teachers to maintain order and organisation in the classroom to achieve an appropriate environment in the learning of their students. Examples of these strategies are the reduction of the ratio, the establishment of routines and rules, encourage positive personal relationship and respect the differences among schoolmate or design classroom programmes that take into account the needs of students with Special Educational Needs (SEN) and the group in general.

- $\quad$ Teaching strategies and learning assessment: these are techniques used by the teacher so that their students can learn more effectively, since these techniques contribute to improve the performance. Some examples could be formative or continuous evaluation as a method to attend to diversity in the classroom (Mastropieri, 1987) or techniques such as thinking out loud, motivation strategies, problem solving or memorization, etc.

- $\quad$ Grouping strategies: they refer to the formation of groups of different sizes that attend to different criterions according to the needs of the students and the objectives set by the teacher. These strategies are important because they improve results and provide flexibility in the programming. These groups can be modified or dissolved according to the needs that arise in the classroom. It is preferable that there are few and homogeneous groups instead of many groups heterogeneous.

- Adaptation strategies (activities and materials): these strategies are a combination of adaptations that are made by the teachers in the materials, in the activities that they programme or in the format of these activities, in order that all students have access to the curriculum and encourage their participation. Some of these strategies are, for example, the development of activities of different levels of demand, the analysis and breakdown of tasks in simpler sequences or the design and adaptation of materials.

In summary, to carry out strategies that improve the inclusion of students with Special Educational Needs (SEN), it is necessary keep in mind the personal and material resources, methodology, organization and planning in the classroom (Valenzuela, Guillén \& Campa, 2014).

Thus, it is necessary that schools have this type of resources; personnel (teachers and others trained professionals), methodological, material and organizational. In short, professionals of education with a positive attitude, who dominate different inclusion strategies (Gento 2007; Valenzuela, Guillén, Campa, López \& León, 2012).

Finally, to carry out inclusion in our schools, we can do the following: observe the differences of students as new learning opportunities, start with previous practices and knowledge that students have, create conditions that encourage to taking risks by offering support all time, use available resources to offer learning support, take into account possible barriers to participate and address them with supports or, for example, reflect and experiment more inclusive practices from observing some of these practices in coworkers (Rubio, 2009). 


\section{4.-Discussion.}

Nowadays, teachers have shown a positive attitude and good predisposition towards inclusion. However, educational inclusion strategies are unknown and the practice of these strategies is not widespread (Folco, 2013).

Some authors agree on the idea of equitable education in order to offer all students the same learning opportunities according to their characteristics and uniqueness. That is, teachers should consider all students as part of the community. In addition, the entire educational community must be aware of the benefits of differences and learn from them to develop in the personal, professional, curricular, etc. sphere (Calvo, et al., 2006; Rubio, 2009; Mondaca, et al., 2018).

The revised research shows that the authors agree that educational inclusion should be based on organizational, didactic, activity adequacy, grouping, flexible schedule, personal resources and materials (Cardona, et al., 2000; Gento 2007; Chiner, 2011; Valenzuela, et al., 2012; Vicuña, 2013; Valenzuela, et al., 2014; Hernandez \& De Barros, 2016).

\section{5.-Conclusion.}

As Tony Booth's definition (1996) on integration and UNESCO's definition (2008) on inclusion have been seen as very similar. Therefore, although at the language level there is talk of inclusion, at the level of real practice in the school integration is still practiced. In other words, there has been a change in terminology, but not in practice. Therefore, to move from an inclusive to an inclusive school, the school must be made up of the entire educational community. Without excluding families, neither students nor teachers. Since sometimes the PT teacher is isolated and excluded from other teachers. If the TEACHER of PT or inclusion, the students who attend can hardly be excluded (De Barros \& Hernández, 2016).

In addition, the way students are viewed, without differentiating between normal and disabled students, but all are students and each has learning possibilities thus facilitating the normalization of their situation (Folco, 2013; De Barros \& Hernández, 2016).

Throughout this research, it has been possible to confirm that in order to achieve real inclusion, it is necessary to have the positive attitude and good predisposition of teachers towards inclusion. In addition, strategies and resources must be carried out. It is also necessary to learn from the difference and to start from the singularities and needs of each one so that all students have the opportunity to acquire the knowledge and skills necessary to develop in their social, family and personal environment (Gallego, 2002; Bald, 2013; Folco, 2013).

Definitely, this research has shown that the educational inclusion of students with NEAE has followed a long and difficult process. Therefore, it is considered appropriate that the advancement of inclusive school should not be done in a hasty manner, but that every progress is solid and definitive. 


\section{6.-References.}

Calvo, G., Camargo, M., Gutiérrez, M. (2006). Política educativa, equidad y formación docente. Bogotá: D'vinni.

Calvo, G. (2013). La formación de docentes para la inclusión educativa. Páginas de Educación, 13(1), 19-35.

Chiner, E. (2011). Las percepciones y actitudes del profesorado hacia la inclusión del alumnado con necesidades educativas especiales como indicadores del uso de prácticas educativas inclusivas en el aula (Tesis doctoral). Universidad de Alicante, España.

Damm, X. (2008). Educación inclusiva ¿Mito o realidad? (Informe Final). Santiago, Chile: FONIDE, Ministerio de Educación.

Folco, M. (2013). Estrategias docentes en la inclusión de niños y niñas en situación de vulnerabilidad. Revista Internacional de Educación para la Justicia Social, 2(2), 255-270.

García, J. (2017). Evolución legislativa de la educación inclusiva en España. Revista Nacional e Internacional de Educación Inclusiva, 10(1), 254-264.

Gobierno de España (2006). Ley Orgánica 2/2006, de 3 de mayo, de Educación. Boletín Oficial del Estado, 106, 1-110.

Grande, P. y González, M. M. (2015). La educación inclusiva en la educación infantil: propuestas basadas en la evidencia. Tendencias pedagógicas, 26, 145-162.

Hernández, A., De Barros, C. (2016). Neurociencia y tecnología en la inclusión educativa. Granada: Gami. 